\title{
Factors influencing the adoption of biogas digesters in rural Ethiopia
}

\author{
Melaku Berhe $^{1 *}$, Dana Hoag ${ }^{2}$, Girmay Tesfay ${ }^{1}$ and Catherine Keske ${ }^{3}$
}

\begin{abstract}
Background: Increasing energy demands on farm households in Ethiopia have escalated challenges related to land degradation, indoor air quality, and rural economic development. Soil deterioration followed by reduced carbon sequestration compounds the adverse effects of environmental degradation and climate change. The Ethiopian government has disseminated thousands of bio-digesters across rural villages with the hope that introducing biodigesters to rural farm households would address all of these issues. However, there is scant information about how households make energy choices and consequently how the introduction of biogas energy will affect income and the environment in these rural agricultural communities. Therefore, this study aims to verify how biogas energy adopters make decisions about their energy consumption and how biogas energy use compares to traditional alternatives such as firewood, charcoal, and dried animal dung.

Methods: Quantitative data were gathered using semi-structured questionnaires of 300 farmers in the Tigray region of Ethiopia, following the collection of qualitative data obtained via focus groups. Using descriptive analysis, we quantified weekly consumption of traditional energy sources and major reasons why households choose each energy source. We estimated a multivariate probit model and conducted correlation tests to verify the use of biogas energy as a substitute or complement for traditional energy sources.

Results: Results show that a household's choice for biogas energy was statistically and positively correlated to both firewood and charcoal use. Despite biogas digester adoption in several households, the majority continue to depend upon traditional energy sources. This suggests that overall household energy consumption increases with the availability of biogas digesters. The study reveals that the size of cattle holding, working age, gender, access to electricity, access to credit services, and livestock mobility influence household energy choices.

Conclusions: The study concludes that household biogas energy use remains below expectations, even though subsidies make the units affordable for small farmers. We assert that households are more likely to adopt technologies that facilitate cooking food, baking injera, and preparing coffee. Biogas utilization might improve if farmers have access to improved stoves and credit services. However, policy makers also need to consider the possibility that providing access to biogas digesters may actually increase the use of traditional fuel sources and have the reverse effect than that intended.
\end{abstract}

Keywords: Biogas energy, Energy choice, Ethiopia, Multivariate probit model, Tigray

\footnotetext{
* Correspondence: melakuberhe@gmail.com

${ }^{1}$ Department of Agricultural and Resource Economics, College of Dryland Agriculture and Natural Resources, Mekelle University, P.O. Box 231, Mekelle, Ethiopia

Full list of author information is available at the end of the article
} 


\section{Background}

More than 70\% of the population in Africa relies on fuelwood energy sources [1], whereby $90 \%$ of the resource is extracted from natural forests [2]. Excessive energy consumption derived from forest resources disrupts carbon sinks, which compounds the adverse effects of climatic change $[3,4]$. This has further escalated occurrences of recurring droughts, flooding, land degradation, and loss of soil nutrients, which directly affect livestock and crop yield [5]. Consequently, energy sources in Africa that are perceived as environmental friendly have received growing attention [6,7], especially when these sources also have the potential to alleviate energy poverty, which is generally defined as limited or lack of access to modern energy infrastructure [4].

One sustainable energy alternative that has potential to provide low-cost energy without the need to harvest wood is a biogas digester [8-10]. Capturing biogas during waste decomposition and using it for energy (herein call the "biogas digestion" process) can reduce the use of fuel-wood energy [12-15], and hence lessens the degradation of local forests. This commensurately reduces the greenhouse gas (GHG) emissions into the air and improves carbon sequestration potential [11]. Biogas digesters can also improve rural livelihoods through energy cost savings and reduced labor to harvest wood and by providing organic fertilizers that can enrich soil fertility [16-18]. The introduction of biogas energy sources, for instance, in China and India, has effectively improved livelihoods of rural communities where it has considerably decreased the dependence on energy consumption from fossil and wood sources [16, 19-22].

In many African nations, biogas technology has become an important strategy to provide sustainable energy [3, 7, 15, 23-25]. In Ethiopia, the increasing rate of deforestation coupled with the strident pace of population growth has escalated energy poverty, severe land degradation, and loss of soil fertility [18]. The Ethiopian government decided to subsidize bio-digesters in rural farm households [7], in an effort to provide a substitute for firewood, charcoal, dried animal dung, and other materials. The National Biogas Program (NBP) was implemented to test the feasibility of biogas in actual farm settings. During the program's first phase, the government disseminated 14,000 bio-digesters across four regional states, Tigray, SNNP (Southern Nations, Nationalities and Peoples), Oromia, and Amhara [18]. More than $70 \%$ of the nation's population lives in these regions, whose energy demand entirely depends on natural forests [22].

Although biogas energy provides promise for Ethiopia, to date, no study has evaluated how biogas digesters influence households' energy choices. To our knowledge, there has not been a quantitative analysis to predict when households will substitute away from traditional energy sources. Until more is known about the decision-making in these rural households, it will be difficult to predict whether biogas technology can be successfully adopted in Ethiopia and other African countries. Reports from previous studies indicate that a household's energy choice could be influenced by various socioeconomic variables, environmental changes, demographic compositions, and social factors $[3,7,15,18]$. However, we are unaware of any studies that have addressed whether biogas systems substitute or complement other energy sources. Furthermore, no known study has looked at Ethiopian household participation in the NBP or evaluated whether the NBP is cost-effective for households or the government.

In this study, we use data from a survey of over 300 NBP participants in the Tigray region of Northern Ethiopia to examine how the program has affected households' energy choices. The primary research questions are (1) What energy sources are people using in these households, and why are they choosing those sources? (2) Are biogas digesters a complement or substitute for firewood, charcoal, and dried animal dung? (3) What factors predict energy choices? (4) What are the costs and benefits of biogas digesters to farm households? Other important benefits, such as the impact of biogas digesters on forest degradation or improved household health through cleaner burning fuels were beyond the scope of this study and prevent us from making an estimate of social welfare from the NBP.

In summary, up until this point, there has been a lack of evidence on the extent of biogas adoption in rural areas or how to predict whether adopters substitute or complement biogas energy with other energy sources. Biogas digesters have considerable potential to improve the well-being of rural households and to reduce dependence on fuel-wood energy sources, but it is difficult to predict the extent of this, without first undertaking research to verify the factors that influence biogas adopters to replace consumption of firewood, charcoal, and animal dung with biogas sources.

Hence, this study makes three contributions. First, it captures household preferences about energy alternatives in a rural, developing country setting. Second, it determines whether biogas digesters are a complement or substitute for firewood, charcoal, and dung. Finally, when these first two contributions are combined with information about the financial feasibility of the NBP, this study shows that biogas digesters are a feasible way to shift the focus away from firewood and natural resources towards a renewable resource that, in addition to reducing the impact on natural resources, can provide several other benefits such improved indoor air quality, organic fertilizer, and additional income. We believe that policy makers will incorporate results from this study to explore how to make the NBP program more successful. 


\section{Methods}

\section{Methodological framework}

This study is based on a survey of 300 small farmers in the Tigray region of Northern Ethiopia. The results are presented in four parts. First, we present information from the survey, including socioeconomic status, energy consumption, and energy sources. Next, we conduct three analyses. In the first analysis, we look at what determines which energy sources small farmers choose to use. In the second analysis, we look at how the choice of biogas might complement or substitute for other energy sources such as wood or charcoal. Finally, we review the financial feasibility of the NBP, as far as it relates to farm households. A full welfare analysis was beyond the scope of this study because we lacked information about all costs and benefits.

Two dominant strands of literature explain household behavior on energy choice, the "energy ladder" and "energy stacking" [26-28]. The energy ladder holds the view that a given household that has a wide range of energy options can move from one level to another based on income level [5, 29-31]. Stretching along the energy ladder from bottom to top, the theory has ranked the energy sources into three levels: primitive, transitional, and modern [5, 32]. The primitive energy source is located at the bottom of the energy ladder, which mainly includes firewood, agricultural residues, and animal dung [18, 32, 33]. In the middle of the ladder, the transition energy source comprises charcoal, kerosene, and coal. Advanced energy sources such as electricity, LPG (liquefied petroleum gas), biogas, and other bio-fuels are ranked at the top of the ladder. The second theory is energy stacking, which contends that households largely depend on multiple energy sources [34-36]. Given that affordable fuel sources are readily accessible, households continue using more fuel options as long as they find that fuel sources generate maximum utility [37]. Even if their income level increases, instead of replacing old energy sources by new ones, households continue utilizing older sources and expand their use of energy resources [36]. In most cases, households make multiple decisions to use a variety of fuel sources like firewood, charcoal, biogas, kerosene, electricity, etc. [38, 39]. The choice of one energy source may produce another energy source because of their complementary nature (for example, firewood utilization produces charcoal). Unlike the energy ladder, energy stacking theory indicates that a household's energy choice does not necessarily follow a unidirectional process.

In rural areas where modern energy options are not accessible, fuel-wood remains a very important energy source irrespective of household income. A study done in Ethiopia indicated that households did not switch to cleaner or more efficient energy sources when their income increased $[40,41]$. Most people in urban and rural areas of developing countries depended on firewood as they found it cheaper and more accessible than other alternatives. This suggests that households depend on one or more energy sources as long as they obtain a maximum threshold level of utility they want to achieve, which is most consistent with energy stacking theory.

In the Tigray study area, energy sources are obtained from biogas digesters, firewood, charcoal, and dried dung. Households make four choice decisions, as each activity provides them a certain threshold level of utility. As shown in Eq. 1, the dependent variable, energy choice, is based on four options, each having a discrete binary variable taking value 1 if the energy source is chosen and 0 if it is not chosen. To formulate the causal relationships, we used a multivariate probit model. The multivariate probit model is characterized by a set of " $n$ " binary-dependent variables $\left(y_{\mathrm{i}}\right)$ with outcome of binary decisions for each energy choice. Following the work of previous authors [43], the functional relationships of household choices among the energy sources are given by:

$$
\begin{aligned}
y_{\mathrm{Bi}}^{*} & =f\left(x_{1 \mathrm{j}}, \theta_{\mathrm{j}}^{\prime}\right) \quad \text { (Energy Choice from Biogas) where } y_{\mathrm{Bi}} \\
& =\left\{\begin{array}{l}
1 \text { if } y_{\mathrm{Bi}}^{*}>0 \\
0 \text { otherwise }
\end{array}\right. \\
y_{\mathrm{Fi}} * & =f\left(x_{2 \mathrm{j}}, \theta_{2 \mathrm{j}}^{\prime}\right) \text { (Energy Choice from Firewood) where } y_{\mathrm{Fi}} \\
& =\left\{\begin{array}{l}
1 \text { if } y_{\mathrm{Fi}}^{*}>0 \\
0 \text { otherwise }
\end{array}\right. \\
y_{\mathrm{Ci}}^{*} & =f\left(x_{3 \mathrm{j}}, \theta_{3 \mathrm{j}}^{\prime}\right) \text { (Energy Choice from Charcoal) where } y_{\mathrm{Ci}} \\
& =\left\{\begin{array}{l}
1 \text { if } y_{\mathrm{Ci}}^{*}>0 \\
0 \text { otherwise }
\end{array}\right. \\
y_{\mathrm{Di}} * & =f\left(\begin{array}{l}
x_{4 \mathrm{j}}, \theta_{4 \mathrm{j}}^{\prime}
\end{array}\right) \text { (Energy Choice from Dried Dung) where } y_{\mathrm{Di}} \\
& =\left\{\begin{array}{l}
1 \text { if } y_{\mathrm{Di}}^{*}>0 \\
0 \text { otherwise }
\end{array}\right.
\end{aligned}
$$

where B, F, C and D represent energy choices obtained from biogas, firewood, charcoal and dried dung respectively; $y_{i}^{*}$ represents the unobserved outcomes of energy choices, $y_{i}$ denotes the observed outcome of energy choice, $x_{\mathrm{i}}$ is the vector of explanatory variables, and $\theta_{\mathrm{i}}$ is a vector of coefficients. The decision made by each household to choose among the four energy options, given by $y_{i}^{*}$ in Eq. (1), is a latent variable and its error terms are assumed to be correlated with the error terms arisen from the observed choice given by $y_{\mathrm{i}}$.

With the assumption that the error terms $\left(\varepsilon_{1}, \ldots \varepsilon_{n}\right)$ of the multivariate probit model are normally distributed, the probability of the four energy choices (discrete dependent variables) is expressed at $n \times n$ covariance matrix of $[\rho i j]$. Denoting the row and column correlation coefficients by $i$ and $j$, the cumulative distribution function of the standard normal distribution function of the model $\phi\left(\varepsilon_{1}, \varepsilon_{2}, \varepsilon_{3}, \varepsilon_{4}, \rho_{\mathrm{ij}}\right)$ is shown as: 


$$
\begin{gathered}
P_{\mathrm{i}}\left(y_{\mathrm{Bi}}=1, y_{\mathrm{Fi}}=1, y_{\mathrm{Ci}}=1, y_{\mathrm{Di}}=1\right)=P_{i} \\
\left(y_{\mathrm{Bi}}^{*}>0, y_{\mathrm{Fi}}^{*}>0, y_{\mathrm{Ci}}^{*}>0, y_{\mathrm{Di}}^{*}>0 ; \rho_{\mathrm{ij}}\right) \\
=\mathrm{P}_{\mathrm{i}}\left(\mathrm{x}_{1 \mathrm{i}}^{\prime} \theta_{1 \mathrm{i}}, \mathrm{x}_{\mathrm{n}}^{\prime} \theta_{\mathrm{n}} ; \rho_{\mathrm{ij}}\right) \\
=\int_{-\mathrm{x}_{\mathrm{ii}}{ }^{\prime} \theta_{\mathrm{li}}}^{\infty} \int_{-\mathrm{x}_{2 \mathrm{i}}{ }^{\prime} \theta_{2 \mathrm{i}}}^{\infty} \ldots \times \int_{-\mathrm{x}_{\mathrm{n}}^{\prime} \theta_{\mathrm{n}}}^{\infty} \\
\varphi\left(\varepsilon_{1}, \ldots \varepsilon_{n}, \rho_{i j}\right)^{\prime} d \varepsilon_{n} \ldots d \varepsilon_{2} d \varepsilon_{1}
\end{gathered}
$$

where $P_{\mathrm{i}}$ is the likelihood probability function, $X^{\prime}$ is a vector of explanatory variables, $\theta$ is a vector of coefficients of each explanatory variable, and $\varepsilon_{\mathrm{i}}$ represents random error terms distributed at zero means and constant variance with unitary diagonal elements. The probability of choosing the four energy choices (biogas, firewood, charcoal, and dung) is given by " $P_{\mathrm{i}}$ " in Eq. (2); therefore, the marginal effect of each explanatory variable in a multivariate standard normal distribution is measured by:

$$
\partial P_{\mathrm{i}} / \partial X_{\mathrm{i}}=\theta\left(X^{\prime} \theta\right) \theta_{\mathrm{i}}, \quad n=1,2, \ldots, n
$$

where $P_{\mathrm{i}}$ is the probability of events to use each energy choice, $\theta\left(X^{\prime} \theta\right)$ is the standard normal cumulative density distribution function, and $X$ and $\theta$ are vectors of explanatory variables and their coefficients respectively [42]. In addition to identifying which variables best explain what type of energy people use, the correlation of error terms reveals whether the energy sources are complements or substitutes. This reveals if increasing the availability of biogas will increase or decrease total energy use.

\section{Study area and sampling}

This research was based on a cross-sectional data gathered in 2015 from two districts namely, Ofla and Hintalo-Wejerat. The two districts are found in the Tigray region of northern Ethiopia. Ofla is situated in the southern part of the region; it is geographically located at $12^{\circ} 30^{\prime}\left(12.5^{\circ}\right)$ North latitude and $39^{\circ} 20^{\prime}\left(39.33^{\circ}\right)$ East longitudes with an average elevation of $2667 \mathrm{~m}$ above sea level. In the southeast of the Tigray region, HintaloWejerat is situated at $13^{\circ} 09^{\prime}\left(13.8^{\circ}\right)$ North latitude and $38^{\circ} 39^{\prime}\left(38.8^{\circ}\right)$ East longitude with an average elevation of $1197 \mathrm{~m}$ above sea level. From these districts, we also obtained financial data records of 2011 through 2015 that illustrate fixed and net variable costs for installation of a bio-digester contrasting with net benefits.

The survey employed two stages. First, a reconnaissance qualitative research phase was completed for a broader understanding about the current household energy choices, especially with regard to biogas digesters.
During this stage, we conducted a series of discussions were held with various representative stakeholders drawn from farmers, extension workers, and agricultural experts. The preliminary information gathered during the qualitative research phase was used to refine the study objectives, sampling methods, and the survey instrument. In the second stage, we stratified the two districts into two climatic zones depending on their agro-ecological locations. Overall, there were 1369 cattle owners who already adopted biogas digesters; among these, 730 (658 males and $72 \mathrm{fe}$ males) were in Hintalo-Wejerat and 639 (546 males and 93 females) resided in Ofla. From this population, a representative sample size was estimated at $95 \%$ confidence level with precision of 0.05 [14].

$n=\frac{N Z^{2} P(1-P)}{N \cdot e+Z^{2} P(1-P)}$ where $n=$ the sample size, $N=$ the population size, $Z=$ confidence level at $95 \%, Z=1.96$, $P=$ estimated population proportion (0.5), and $e=$ the precision level at $5 \%$.

Therefore, $n=\frac{1369(1.96)^{2} 0.5(0.5)}{1369(0.05)+(1.96)^{2} 0.5(0.5)}=299.89$

Of the 300 representative sampled respondents, 160 (146 males and 14 females) were proportionately drawn from Hintalo-Wejerat and 140 (118 males and 22 females) from Ofla.

\section{Survey results and discussion Socioeconomic status of the respondents}

Descriptive statistics are presented in Table 1. In the majority of households $(N=292)$, ages ranged between 19 to 71 years with an average of 43.74 years. Eight households had a mean age of 67.75 years. Therefore, most respondents were aged for an active labor force. On average, the family size in each household reached about 5.4 members, with a minimum of 2 and maximum 10 . The mean land size owned by each farmer was about $0.32 \mathrm{ha}$, and land farmed through a share-in system was about 1.93 ha. Each household owned an average of 6.94 cattle and varied between 1 and 25 . The estimated average income annually earned from cropping and livestock was Birr $^{1} 3592.06$ and 1684.49 , respectively.

Biogas digesters were connected to toilets and the households collected animal dung to feed digesters every morning. Similarly, group discussants and key informants expressed that family members took part in feeding their biogas digesters with animal dung and other residue materials. Largely, females contributed more labor inputs than men in cleaning, cooking, taking bioslurry to back yards, and mixing dung with water to ensure its proper functioning.

\section{Energy consumption}

Table 2 presents the quantity of traditional energy sources consumed at the household level. These rural 
Table 1 Socioeconomic characteristics of biogas adopters

\begin{tabular}{|c|c|c|c|c|c|}
\hline Variables & Observation & Mean & Standard deviation & Minimum & Maximum \\
\hline Age of household $15-64$ years & 292 & 43.74 & 10.33 & 19 & 64 \\
\hline Age of household above 64 years & 8 & 67.75 & 2.05 & 65 & 71 \\
\hline Shared-in-land size in hectares & 300 & 1.93 & 0.53 & 1 & 3 \\
\hline Owned land size in hectares & 300 & 0.32 & 0.07 & 0.2 & 1.25 \\
\hline Family size & 300 & 5.40 & 1.52 & 2 & 10 \\
\hline Cattle holding & 300 & 6.94 & 2.73 & 1 & 25 \\
\hline Income from cropping/year & 300 & 3592.06 & 1152.11 & 1200 & 7960 \\
\hline Income from livestock/year & 300 & 1684.49 & 1913.72 & 0 & 7650 \\
\hline Income from agricultural wages/year & 300 & 209.43 & 292.96 & 0 & 2333 \\
\hline Income from non-agricultural wages/year & 300 & 219.02 & 591.78 & 0 & 320 \\
\hline
\end{tabular}

households relied on large quantities of these traditional energy sources, commonly obtained from firewood, charcoal, dung, and kerosene. Animal dung was the main source of energy, with households consuming an average of $19.3 \mathrm{~kg}$ weekly. Firewood consumed at the household level was $14.6 \mathrm{~kg} /$ week, whereas consumption of charcoal was $1.5 \mathrm{~kg} /$ week. It was found that households used to burn dried dung rather than place it in the bio-digesters. Households elucidated that kerosene for energy was negligible. In addition, the average amount of kerosene consumed in liter was the least among other energy sources (Table 2).

The findings indicate that animal dung was the dominant source of energy. There are three possible reasons that might explain this result. First, availability of firewood and charcoal in the Tigray region has become very limited. Second, animal dung is available year-round, and third, animal dung in the study area is the cheapest and most affordable energy source. Hence, households largely used animal dung for cooking and heating.

\section{Reasons reported for using different energy sources}

Rural households switch from one energy source to another depending on their local conditions. As shown in Table 3, about $20.33 \%$ of the households reported that they had access to gather wood sources either from own homesteads (for example, eucalyptus trees) or from communal areas. Households with access to gather firewood from communal areas reported that they would keep utilizing it because of its suitability for baking injera ${ }^{2}$, preparing coffee, cooking stew, and heating. Furthermore, 39.7\% of the households tended to choose charcoal due to its versatility for cooking, roasting, and baking bread.

As reported, households chose biogas energy because of its compatibility for cooking and lighting. In addition, biogas allowed them to save large costs that might otherwise be spent for purchasing firewood and charcoal. Despite several benefits that biogas digesters could provide, households were not able to rely on it fully because they lacked compatible cook stoves for making coffee and baking bread and injera. The absence of appropriate stoves compelled households to balance their energy requirements via collection of additional energy sources such as firewood, charcoal, and dried dung. For instance, $18.33 \%$ of the households mentioned that they utilized animal dung, owning to its availability and cheapness in price. In most rural areas, people (mostly women) collected dung around the home. Despite the adverse effects of indoor smoke released from dung, households still continue to use it for cooking stew, baking injera, and making coffee.

\section{Results and discussion}

Determinants of energy choices

Table 4 illustrates regression outputs of the multivariate probit model. The estimated results show that energy choice of biogas adopters was significantly influenced by gender, access to credit services, location (HintaloWejerat or Ofla), cattle holding, age, livestock mobility, and access to electricity. The coefficients describe the influence of each explanatory variable on each of the four energy choices (dependent variables). Given

Table 2 Weekly consumption of traditional energy options

\begin{tabular}{|c|c|c|c|c|c|c|}
\hline Variables & Unit & Observation & Mean & Standard deviation & Minimum & Maximum \\
\hline Firewood & $\mathrm{kg}$ & 300 & 14.6 & 3.124 & 7.75 & 23.25 \\
\hline Charcoal & $\mathrm{kg}$ & 300 & 1.5 & 0.52 & 1 & 3 \\
\hline Dung & $\mathrm{kg}$ & 300 & 19.3 & 7.83 & 8 & 42 \\
\hline Kerosene & L & 300 & 0.02 & 0.12 & 0 & 1 \\
\hline
\end{tabular}


Table 3 Major reasons for choosing the available energy options

\begin{tabular}{|c|c|c|c|}
\hline Energy type & Observation & Percentage & Major reasons \\
\hline Firewood & 61 & 20.33 & $\begin{array}{l}\text { - Suitable for injera baking } \\
\text { - Preferable for coffee preparation in rural areas } \\
\text { - Traditionally known for cooking and lighting }\end{array}$ \\
\hline Charcoal & 119 & 39.67 & $\begin{array}{l}\text { - Compatible for cooking stew } \\
\text { - Culturally accepted for making coffee } \\
\text { - Efficient for baking bread }\end{array}$ \\
\hline Biogas & 65 & 21.67 & $\begin{array}{l}\text { - Suitable for cooking and lighting } \\
\text { - Low cost once installed } \\
\text { - Replaces the high cost of purchasing for firewooc } \\
\text { and charcoal }\end{array}$ \\
\hline Dung & 55 & 18.33 & $\begin{array}{l}\text { - Its availability at home and outside } \\
\text { - Cheap or no cost with its easily accessibility } \\
\text { - Used for cooking bread, baking injera, and } \\
\text { making coffee }\end{array}$ \\
\hline
\end{tabular}

results from the regression, the significance level of each explanatory variable represents the probability accounted for in variations contained in each dependent variable (biogas, dried dung, firewood, and charcoal).

Results showed that female-headed households were significantly more likely to utilize biogas energy. This might be because women in the rural areas of Ethiopia were responsible for handling family-related duties such as cooking and baking injera, for which they priory seek sufficient and safe energy source using biogas energy. In agreement with this finding, research results reported by another study [45] showed that women, who spend time in the kitchen, are exposed to indoor smoke and are more likely to choose better energy sources such as biogas energy. This finding has interesting policy implications in the sense that biogas dissemination may contribute to alleviating women's energy and labor burdens and indirectly contribute to restoration of denuded areas.
Access to credit services is an important variable in rural energy choices. The availability of credit positively and significantly influenced adoption of biogas energy in this study. A possible reason may be because it enabled biogas adopters to get their digesters repaired and maintained. Hence, availability to credit might be an important addition to any program that aims to help producers adopt biogas energy. These findings are supported in other studies. Biogas adopters in Asia and Africa who had better access to financial services were able to purchase materials needed to function their bio-digesters [46]. A recent study conducted in Ethiopia similarly reported that availability of credit services in rural areas was likely to ease financial constraints that require running bio-digesters [18]. This finding is also consistent with other studies that show that the availability of financial resources to repair biogas digesters affects the financial feasibility of these systems in many developed regions of the world, including the Western United States [48].

Table 4 Determinants of energy choices using multivariate probit model

\begin{tabular}{|c|c|c|c|c|c|c|c|c|}
\hline \multirow[t]{2}{*}{ Explanatory variables } & \multicolumn{2}{|l|}{ Firewood } & \multicolumn{2}{|l|}{ Charcoal } & \multicolumn{2}{|l|}{ Biogas } & \multicolumn{2}{|c|}{ Dried dung } \\
\hline & Coef. & Stan error & Coef. & Stan error & Coef. & Stan error & Coef. & Stan error \\
\hline Cattle holding & 0.0132 & 0.0351 & 0.0446 & 0.0431 & -0.1129 & $0.0485^{* *}$ & -0.0250 & 0.0386 \\
\hline Household members age 15 to 64 & 0.0352 & 0.0528 & -0.0861 & 0.0699 & -0.2024 & $0.0739^{* * *}$ & -0.0980 & 0.05753 \\
\hline Dummy variable female $=1$ & -0.3075 & 0.3389 & -0.8338 & $0.3629 * *$ & -1.268 & $0.5386^{* *}$ & 0.0753 & 0.3880 \\
\hline Access to electricity & 0.8505 & $0.3290^{* * *}$ & -0.4368 & 0.4554 & 0.6605 & 0.4538 & 0.8752 & $0.327^{* * *}$ \\
\hline Access to credit & 0.7711 & $0.2483^{* * *}$ & -0.2945 & 0.3110 & 1.528 & $0.3665^{* * *}$ & 0.4561 & 0.2675 \\
\hline Storing bio-slurry & -0.0162 & $0.0073^{* *}$ & -0.0005 & 0.0087 & 0.0104 & 0.0115 & 0.0004 & 0.0077 \\
\hline Location & -0.1185 & 0.1916 & -0.0564 & 0.2232 & -0.1415 & 0.2921 & 0.4672 & $0.2129 * *$ \\
\hline Livestock mobility & 0.4364 & $0.1948^{* *}$ & -0.2695 & 0.2424 & 0.1569 & 0.2923 & 0.0287 & 0.2092 \\
\hline Constant & -1.069 & 0.9332 & 2.9480 & 1.108 & -6.7070 & 149.88 & -1.2030 & 1.0240 \\
\hline
\end{tabular}

aprobit model: only explanatory variables with at least one significant variable shown. Variables not shown include household members over 64 , goat total livestock unit (TLU), cropping, diversity of income, working time, land size, availability of waste residues, access to extension services, type of stove, and income level

Significance level: $* * * 1 \%$ and $* * 5 \%$ 
Location has a significant influence on dried dung as an energy choice. Farms located in Hintalo-Wejerat were more likely to use dried dung as compared to those living in Ofla. Availability of better forest and bush coverage in Ofla may be the key reason that households were less likely to choose dried dung. The implication is that the success of supporting the adoption of biogas digesters in rural households may depend on the availability of alternative energy sources. In the case of Tigray, it will depend on how farmers see biogas digesters compared to dung in one region versus wood and charcoal in the other. Similar research results reported by others [5] indicated that dwelling location has a significant influence on the energy choice of households.

As illustrated in Table 4, cattle holding were negatively and significantly correlated to the probability of choosing biogas energy. The negative correlation indicates that there is a higher probability that biogas adopters will substitute traditional energy sources (firewood, charcoal, and dried dung) with biogas energy. The possible reason might be that biogas adopters possessing a high number of cattle are more likely to collect more dung. The results are in congruence with previous research findings reported about Africa and Asia. Studies done by [46] in Uganda, [18] in Ethiopia, and [19] in Bangladesh reported similar findings in that cattle holding significantly and positively affected household's choice to use biogas energy.

The age of household head was negatively and significantly related to biogas energy. A 1-year increase in the household heads' age corresponds to a decreasing probability for choosing biogas energy. The implication is that younger households are more likely to utilize energy from biogas digesters. Older households may not be interested in the laborious task of feeding and handling of bio-digesters, choosing instead to continue consuming traditional energy sources, mainly firewood, charcoal, and animal dung. In congruence with this finding, others [47] reported that an increase in the age of household head correspondingly stimulates farmers in Nigeria to choose traditional energy sources. Contrary to these findings, [46] in Uganda and [37] in Ethiopia have indicated that households tend to choose clean and safe energy sources as they get older. These contrary findings show the need for further research.

Livestock mobility practiced by cattle owners was found to have a negative and significant relationship with energy choices for using biogas and charcoal. The influence of livestock mobility on consumption of biogas and charcoal suggests that cattle owners who kept moving from place to place could not utilize energy from both energy sources. In other words, households who experienced livestock mobility might not able to feed bio-digesters with waste materials.
The estimated result for access to electricity was found to have positive and statistically significant association with household's energy preferences towards the use of firewood and dried dung. The positive result suggests that household energy utilization could reflect a complementary relationship between electricity, firewood, and dried dung or an observation that electricity is desirable but still relatively expensive compared to traditional sources. Contrary to this finding, another study [27] found that access to electricity has a negative correlation with a household's choice for fuel-wood sources.

\section{Impact of bio-digesters on traditional energy sources}

Other studies have shown that biogas adopters do not solely depend on bio-digesters to meet their energy needs [7]. They rely on the use of available fuel sources to create stable energy at the household level. In most cases, they allocate traditional fuel energy resources such as firewood, charcoal, and dung to complement or substitute with biogas [18]. Hence, this study attempted to verify whether biogas digesters contribute to the use of traditional energy sources. Traditional sources are used more often when there is a complementary relationship to biogas and less often when biogas is a substitute.

There is an important need to analyze specific energy choices among biogas adopters because biogas adoption by rural farmers ostensibly decreases dependency on firewood, charcoal, and dung. To discover the extent of household's choice among available energy sources, a multivariate probit model was used (Table 5). The model helps distinguish whether there is a causal relationship between household preference and energy alternatives. Results show that the estimated correlation coefficients of the error terms $(\rho)$ representing biogas, firewood, charcoal, and dried dung were statistically significant. The likelihood ratio test confirms that the error terms of the four dependent variables of the energy options (biogas, firewood, charcoal, and dung) were statistically and significantly interdependent on each other. Hence, the null hypothesis of no joint significance of the parameters of the

Table 5 Correlation results of the four energy choices using multivariate probit model

\begin{tabular}{lllll}
\hline Variable correlations & Coefficients & Standard error & $Z$ & $P$ value \\
\hline Charcoal and firewood & 0.274 & 0.139 & 1.97 & $0.049^{* *}$ \\
Biogas and firewood & 0.332 & 0.135 & 2.45 & $0.014^{* *}$ \\
Dried dung and charcoal & -0.469 & 0.181 & -2.59 & $0.010^{* * *}$ \\
Biogas and charcoal & 0.329 & 0.107 & 3.06 & $0.002^{* * *}$ \\
Dried dung and charcoal & 0.017 & 0.139 & 0.12 & 0.903 \\
Dried dung and biogas & -0.237 & 0.143 & -1.67 & 0.096 \\
\hline
\end{tabular}

Likelihood ratio test of rho $21=r h o 31=r h o 41=r h o 32=r h o 42=r h 43=0$ : $\mathrm{chi}^{2}(6)=23.30$ Prob $>\mathrm{chi}^{2}=0.0000$

Significance level: $* * * 1 \%$ and $* * 5 \%$ 
four variables is rejected using the likelihood ratio test, implying the need to apply a multivariate probit model.

The correlation of the error terms of the energy choices confirms the presence of simultaneous decisions made by households in utilizing the energy options either for complementary or substitute purposes. This indeed indicates that the choice for one energy source is affected by the consumption of another energy source. The correlation results support the assumption of interdependence among the energy sources. As illustrated in Table 5, dried dung and biogas were substitutes. The negative correlation coefficient indicates the interchangeability between dried dung and biogas as energy sources. Another study presents a similar finding, indicating that the substitution of burning dried dung with biogas energy not only alleviates health problems arising from indoor air pollutions but also enriches land fertility [25]. To a broader extent, a significant shift from the use of animal dung towards biogas energy is indicative of a pattern towards replacing unclean and unsafe energy technology with modern and safe technology [18].

The findings also show that biogas energy has a positive and significant relationship with energy sources obtained from firewood and charcoal. The positive result suggests that household energy utilization reflects a combination of energy sources that includes biogas, firewood, and charcoal. Biogas adopters might demand additional energy sources if they are unable to obtain sufficient energy from the bio-digesters. In addition, biogas adopters faced with inadequate power for cooking, system failure, or maintenance problems might seek to complement their biogas energy with additional energy sources such as firewood, charcoal, and dung. In this circumstance, biogas adopters needed to fill their energy deficiency by relying on additional resources. This increases the overall demand for energy.

Farmers use multiple sources to ensure the availability of reliable energy and to fuel different household needs. It appears as though many farmers are not willing to rely totally on biogas because they need cook stoves for baking injera and bread. As a result, households consume multiple energy sources simultaneously. Similar findings reported by [18] showed that lack of an injera stove for the existing biogas digesters highly restrained households from using biogas energy effectively. The implication is that the dissemination of biogas energy to rural farmers has not yet realized its full potential. Even though the biogas energy presents potential to improve social and environmental quality, unsustainable energy choices have remained dominant in the study area. These results are also consistent with a research study in Nigeria that showed that biogas adopters tended to utilize a combination of multiple energy sources due to the fact that some energy sources may not always accessible [5].
The positive and significant relationship between firewood and charcoal indicates the existence of strong complementarities. Likewise, others have [44] found that households who burned firewood could also simultaneously produce charcoal, and hence, most households preferred charcoal to firewood because energy from charcoal is smokeless, adds pleasant aroma to food, is suitable for cooking, and is compatible to use with any other stove types. At the household level, people burn firewood to get charcoal though the converse is not true. The complementary nature of these energy sources suggests that biogas adopters utilize biogas energy in combination with other energy sources. As similarly concluded by others [18], the utilization of such energy sources reiterates rural household dependence on forest woods, which is more likely to lead to increasing deforestation and land degradation.

\section{Financial feasibility of biogas digesters}

As a final piece to the biogas puzzle, we sought to determine whether biogas digesters were financially feasible for households. The results presented earlier in the paper largely depend upon biogas being reasonably priced compared to other energy sources. A financial analysis of biogas digesters in the pilot areas of the Tigray region was also conducted to ascertain whether biogas digesters were financially viable for households. As shown in Table 6, the benefits from the biogas digesters include increased yield (teff for this example) due to the enhanced fertilizer provided from the digester and cost savings obtained by offsetting the consumption of traditional fuels. Altogether, these benefits total Birr 4366 per year for the typical farmer. The initial investment is amortized over 25 years at $12 \%$, then added to operating costs, which yields a total operating and investment cost of Birr 1862. This "social" net benefit is Birr 2504 per household. The social net benefit is already sufficient to recommend digesters to households, but since they are subsidized, we computed the private net benefit after a subsidy of Birr 3717 is provided to each household. The social benefit/cost ratio is 2.35 (the total benefits of Birr 4366 per year divided by "social" net benefits of Birr 2504 per household), which is sufficiently large to recommend these systems with relative confidence that they will pay themselves off. While the subsidies are not technically necessary, it is likely that adoption of the biogas systems is less attributable to credit constraints and more attributable to the uncertainty surrounding the efficacy of the systems. The results presented here can help address the latter issue.

\section{Conclusions}

This study examines the contribution of biogas digesters to the energy choices made in rural farm households in 
Table 6 Estimated annual benefits and costs attributed to biogas installation

\begin{tabular}{|c|c|c|c|c|c|}
\hline \multirow[t]{2}{*}{ Benefits and costs } & \multicolumn{4}{|c|}{ Annual benefits and costs in Birr } & \multirow{2}{*}{$\begin{array}{l}\text { Average benefits } \\
\text { and costs in Birr }\end{array}$} \\
\hline & 2011 & 2012 & 2014 & 2015 & \\
\hline Benefit from increased teff yield & - & 3663 & 3905 & 2717 & 3429 \\
\hline Benefit from reduced use of fire wood & - & 180 & 168 & 78 & 142 \\
\hline Benefit from reduced use of charcoal & - & 1152 & 576 & 439 & 723 \\
\hline Benefit from reduced use of kerosene & 72 & 0 & 0 & 0 & 72 \\
\hline Total benefits & & & & & 4366 \\
\hline Initial Investment cost & 12,308 & - & - & - & 12,308 \\
\hline Annual cost of investment ( $12 \%$ interest, 25 years) & 1569 & 1569 & 1569 & 1569 & 1569 \\
\hline Average operating cost & 293 & 293 & 293 & 293 & 293 \\
\hline Total operating costs & & & & & 1862 \\
\hline Net annual social benefit per bio-digester & & & & & 2504 \\
\hline $\begin{array}{l}\text { Net annual private benefit per bio-digester } \\
\text { (minus cost supported by subsidy) }\end{array}$ & & & & & 3717 \\
\hline
\end{tabular}

the Tigray region of northern Ethiopia. A financial analysis shows that biogas systems increase net farm incomes by offsetting fuel costs. We use a survey to examine what energy sources farmers used and to explain why they use them. A quantitative analysis was done with a multivariate probit model. Owing to the help of a pilot program that offered subsidies, several households have already adopted bio-digesters; nevertheless, most of them still depend extensively on firewood, dung, and charcoal for part of their energy. The results indicated that the size of cattle holding, working age, gender, access to electricity, access to credit services, and livestock mobility were statistically significant factors that affect farmer's energy choice. In contrast to the theory of energy ladder, the study found that household's income level did not show a significant influence on energy choice. In fact, the results are more consistent with energy stacking theory that posits that individuals are reliant upon multiple energy sources.

We now return to the four research questions presented at the beginning of the article. Based upon our study results, in some farm households in Ethiopia, biogas digesters serve as a substitute for some traditional fuels. They are also heavily subsidized by the Ethiopian government with the hope of providing several social and environmental benefits. However, despite our analysis showing that biogas digester units can pay for themselves by increased yields and offsetting the costs associated with traditional fuels, farm households continue to use these traditional fuels.

Another important question is how biogas will affect the consumption of other energy sources. A complementary relationship could increase the consumption of a potentially unattainable fuel, like firewood. The results show that a household's energy choice for both biogas and animal dung was a negative relationship, implying their choice to substitute dung for biogas energy. The correlation of the error terms from the probit model were used to more carefully capture unobserved correlations among the available energy alternatives (biogas, firewood, charcoal, and dung). Households made decisions to complement or substitute any of the four energy options, and results of the correlation coefficients statistically confirmed the presence of interdependence among the energy alternatives. It was further found that farmers' choice for biogas energy source was statistically and positively correlated to both firewood and charcoal. This result reveals that policy makers should be careful when introducing biogas digesters, lest they may exacerbate forest degradation rather than reduce it.

Based on these findings, three policy implications can be drawn from this study. First, households' energy choices did not necessarily depend on net income level. Instead, households tended to choose energy sources based on versatility of the sources for cooking, baking injera, and making coffee. It is possible that the traditional fuels influence the taste of these classic Ethiopian dishes, and the process of gathering the fuels used in the preparation of the food reflects multiple cultural and social traditions that provide value in addition to time and fuel savings. Despite the introduction of biogas digesters to the study area, all the households continued utilizing firewood, charcoal, and animal dung. This implies that deforestation and land degradation remain as unresolved challenges in the study areas. Thus, the government along with other partners should consider introducing improved injera stoves at affordable prices. Assuming that there is no impact on the taste of the food, this would help households shift to utilize biogas energy for baking and cooking purposes. Second, households' continual dependence on firewood and charcoal implies the need to pay particular attention to tree plantation 
programs to alleviate shortage of fuel-wood sources across rural areas. Third, the availability of credit services appears to have positive influence on households' choice for using biogas energy. Much like the findings of other studies, this finding implies that access to financial services may assist a farmer to make maintenances and repair when a bio-digester fails to function. Hence, the availability of credit services to rural households goes along with higher probability to utilize biogas energy.

The empirical analysis identified potential limitations that require further research. The study has given a priory emphasis on understanding the pattern of household's energy choices in rural Ethiopia. It did not consider the spillover effects of biogas digesters on rural ecosystems or socio-cultural influences like food preparation routines. By providing a baseline analysis of household energy choices, the study fulfills the preceding condition necessary to take the next step of investigating spillover effects on the environment and rural Ethiopian culture. Although the study does not directly assess the relationship between biogas digesters and the environment, the empirical findings of this study are importantly informative. Based on insights of the study findings, we anticipate that future research may advance knowledge about potential impacts of biogas adoption on the environment and the implementation of energy technologies that have potential to improve the wellbeing of farmers dwelling within the study region and across the world.

\section{Endnotes}

${ }^{1}$ Birr is the unit of money in Ethiopia. One USD was equivalent to 19.32 Ethiopian Birr when data collection was conducted in December 2015.

${ }^{2}$ Injera is tiny and flat-round bread traditionally made from Teff. It is the staple food in Ethiopia and is baked using either electricity or firewood or dung.

\section{Acknowledgements \\ The authors would like to thank Mekelle University and Colorado State University for supporting this study. The authors extend appreciation to the funding provided by Feed the Future Innovation Lab for Collaborative Research on Adapting Livestock Systems to Climate Change (Leader with Associates Cooperative Agreement No. AID-OAA-L-10-00001) and the Vice President Research Fund at Memorial University of Newfoundland-Grenfell Campus.}

\section{Authors' contributions}

All the authors have developed the concept and design the study. While data collection was done by MB, supervision of the survey implementation, writing, and analysis was done by DH, GT, and CK. The manuscript was proofread and revised by all authors. All authors read and approved the final manuscript.

\section{Competing interests}

The authors declare that they have no competing interests.

\section{Publisher's Note}

Springer Nature remains neutral with regard to jurisdictional claims in published maps and institutional affiliations.

\section{Author details}

${ }^{1}$ Department of Agricultural and Resource Economics, College of Dryland Agriculture and Natural Resources, Mekelle University, P.O. Box 231, Mekelle, Ethiopia. ${ }^{2}$ Department of Agricultural Economics, Colorado State University, Box 1172, Fort Collins, CO 80524, USA. ${ }^{3}$ Environmental Studies (Economics), School of Science and the Environment, Memorial University-Grenfell Campus, 20 University Drive, Corner Brook, NL A2H 5G4, Canada.

Received: 12 October 2016 Accepted: 13 March 2017

Published online: 03 April 2017

\section{References}

1. Matsika R, Erasmus BFN, Twine WC (2013) Double jeopardy: the dichotomy of fuelwood use in rural South Africa. Energy Policy 52:716-725

2. Amankwah $E$ (2011) Integration of biogas technology into farming system of the three northern regions of Ghana. J Econ Sustain Dev 2(4):76-85

3. Riti JS, Shu Y. Renewable energy, energy efficiency, and eco-friendly environment (R-E5) in Nigeria. Energy, Sustainability and Society. 2016. doi: 10.1186/s13705-016-0072-1.

4. Arega T, Tewodros T (2017) Household willingness to pay for green electricity in urban and peri-urban Tigray, northern Ethiopia: determinants and welfare effects. Energy Policy 100:292-300

5. Bisu DY, Kuhe A, Lortyer HA. Urban household cooking energy choice: an example of Bauchi metropolis, Nigeria. Energy, Sustainability and Society. 2016. doi: 10.1186/s13705-016-0080-1.

6. Amare $Z Y$ (2014) The role of biogas energy production and use in greenhouse gas emission reduction: the case of Fogera District, Amhara Regional State, Ethiopia. J Multidiscip Eng Sci Technol 1(5):404-410

7. Kamp LM, Forn EB (2016) Ethiopia's emerging domestic biogas sector: current status, bottlenecks and drivers. Renew Sust Energ Rev 60:475-488

8. Kurchania AK (2012) Biomass energy, biomass conversion. Springer Heidelberg, Berlin, pp 91-122

9. Wolde M, Veldkamp E, Mitiku H, Nyssena J, Muys B, Kindeya G (2007) Effectiveness of enclosures to restore degraded soils as a result of overgrazing in Tigray, Ethiopia. J Arid Environ 69(2):270-284

10. Arthur R, Baidoo MF, Antwi E (2011) Biogas as a potential renewable energy source: a Ghanaian case study. Renew Energy 36(5):1510-1516

11. Mshandete AM, Parawira W (2009) Biogas technology research in selected sub-Saharan African countries. Afr J Biotechnol 8(2):116-125

12. Abbasi T (2010) Biomass energy and the environmental impacts associated with its production and utilization. Renew Sust Energ Rev 14(3):919-937

13. Harmse A (2010) Node selection for the integrated sustainable rural development program in South Africa. Dev South Afr 27(3):429-445

14. Chand BM, Bidur P, Upadhyay RM. Biogas option for mitigating and adaptation of climate change. Rentech Symposium Compendium. 2012. In: http://www.ku.edu.np/renewablenepal/images/publications/vol1-2.pdf. Accessed 17 May 2015.

15. Kumar S, Mishra BP, Patel SK, Yaduvanshi BK, Chinchorkar SS, Khardiwar MS (2013) Trends of biogas plants' adoption in Chhattisgarh, India. Spring 2(2):10-13

16. Agoramoorthy G, Hsu GN (2008) Biogas plants ease ecological stress in India's remote villages. Hum Ecol 36(3):435-441

17. Mulinda C, Hu Q, Pan K (2013) Dissemination and problems of African biogas technology. Energy Power Eng. 5(8):506-512

18. Mengistu MG, Simane B, Eshete G, Workneh TS (2015) A review on biogas technology and its contributions to sustainable rural livelihood in Ethiopia. Renew Sustain Energy Rev 48:306-316

19. Kabir H, Yegbemey RN, Bauer S (2013) Factors determinant of biogas adoption in Bangladesh. Renew Sustain Energy Rev 28:881-889

20. Cheng S, Li Z, Mang H, Huba E (2013) A review of prefabricated biogas digesters in China. Renew Sust Energ Rev 28:738-748

21. Aggarangsi P, Tippayawong N, Moran JC, Rerkkriangkrai P (2013) Overview of livestock biogas technology development and implementation in Thailand. Energy Sustain Dev 17(4):371-377

22. National Biogas Program Ethiopia (NBPE) program implementation document. In: http://www.snvworld.org/download/publications/nbp implementation_document_ethiopia_2008.pdf. Accessed 14 June 2015 
23. Mwirigi J, Balana BB, Mugisha J, Walekhwa P, Melamu R, Nakami S, Makenzi P (2014) Socio-economic hurdles to widespread adoption of small-scale biogas digesters in Sub-Saharan Africa: A review. Biomass Bioenergy 70:17-25

24. Okudoh V, Trois C, Workneh T, Schmidt S (2014) The potential of cassava biomass and applicable technologies for sustainable biogas production in South Africa: a review. Renew Sust Energ Rev 39:1035-1052

25. Amigun B, Sigamoney R, Blottnitz HV (2008) Commercialization of bio-fuel industry in Africa. Renewable Sustain Energy 12(3):690-711

26. Heltberg R, Arndt TC, Sekhar NU (2000) Fuelwood consumption and forest degradation: a household model for domestic energy substitution in rural India. Land Econ 76(2):213-232

27. Campbell BM, Vermeulen SJ, Mangono JJ, Mabugu R (2003) The energy transition in action: urban domestic fuel choices in a changing Zimbabwe. Energy Policy 31(6):553-562

28. Ouedraogo B (2006) Household energy preferences for cooking in urban Ouagadougou, Burkina Faso. Energy Policy 34(18):3787-3795

29. Madubansi M, Shackleton CM (2007) Changes in fuelwood use and selection following electrification in the Bushbuckridge Lowveld, South Africa. J Environ Manag. 83(4):416-426

30. Schlag N, Zuzarte F (2008) Market barriers to clean cooking fuels in SubSaharan Africa: a review of literature. Stockholm Environment Institute. In: https://www.seiinternational.org/mediamanager/documents/Publications/ Climate/market_barriers_clean_cooking_fuels_21april.pdf. Accessed 19 September 2014

31. Van der Kroon B, Brouwer R, Van Beukering JHP (2013). The energy ladder: Theoretical myth or empirical truth? Results from a meta-analysis. Renewable and Sustainable Energy Reviews. In: http://www.sciencedirect. com/science/article/piis13640321120006594. Accessed 6 June 2016.

32. Hosier RH, Dowd J (1987). Household fuel choice in Zimbabwe: an empirical test of the energy ladder hypothesis. Resour Energy. 9(4):347-361

33. Barnes DF, Floor WM (1996) Rural energy in developing countries: a challenge for economic development. Ann Rev Energy Environ 21(1):497-530

34. Martins J (2005) The impact of the use of energy sources on the quality of life of poor communities. Soc Indic Res 72(3):373-402

35. Arnold JEM, Kohlin G, Persson R (2006) Woodfuels, livelihoods, and policy interventions: changing perspectives. World Dev 34(3):596-611

36. Masera OR, Saatkamp BD, Kammen DM (2000) From linear fuel switching to multiple cooking strategies: a critique and alternative to the energy ladder model. World Dev. 28(12):2083-2103

37. Tadesse T (2009) Environmental concern and its implication to household waste separation and disposal: evidence from Mekelle, Ethiopia. Resour Conserv Recycl 53(4):183-191

38. Narain U, Gubta S, Veld K (2008) Poverty and resource dependence in rural. India Ecol Econ 66(1):161-176

39. Kebede B, Bekele A, Kedir E (2002) Can the urban poor afford modern energy? The case of Ethiopia. Energy Policy. 30(11):1029-1045

40. Alemayehu G (2014) Anaerobic co-digestion of biodegradable municipal solid waste with human excreta for biogas production. Amer J Appl Chem. 2(4):55-62

41. Salvioni C, Sciulli D, Parod G (2008) Do caring services affect off-farm work? Evid Italy Agric Econ 9(2):42-53

42. Nhemachena C, Hassan R, Chakwizira R (2014) Analysis of determinants of farm level adaptation measures to climate change in Southern Africa. J Dev Agric Econ 6(5):232-241

43. Martínez-Espiñeira R, María MA, García-Valiñas NC (2014) Households' proenvironmental habits and investments in water and energy consumption: determinants and relationships. J Environ Manag 133:174-183

44. Katuwal H, Bohara AK (2009) Biogas: a promising renewable technology and its impact on rural households in Nepal. Renew Sust Energ Rev 13:2668-2674

45. Ghimire PC (2013) SNV supported domestic biogas programs in Asia and Africa. Renew Energy 49:90-94

46. Walekhwa PN, Mugisha J, Drake L (2009) Biogas energy from family-sized digesters in Uganda: critical factors and policy implications. Energy Policy 37:2754-2762

47. Baiyegunhi LJS, Hassan MB (2014) Rural household fuel energy transition: evidence from Giwa LGA Kaduna State, Nigeria. Energy Sustain Dev. 20(1): 30-35

48. Keske $\mathrm{CMH}$ (2012) Anaerobic digestion technology: how agricultural producers-and the environment-might profit from nuisance lawsuits. Nat Resour J 52(2):315-336

\section{Submit your manuscript to a SpringerOpen ${ }^{\circ}$ journal and benefit from:}

- Convenient online submission

- Rigorous peer review

- Immediate publication on acceptance

- Open access: articles freely available online

- High visibility within the field

- Retaining the copyright to your article

Submit your next manuscript at $>$ springeropen.com 